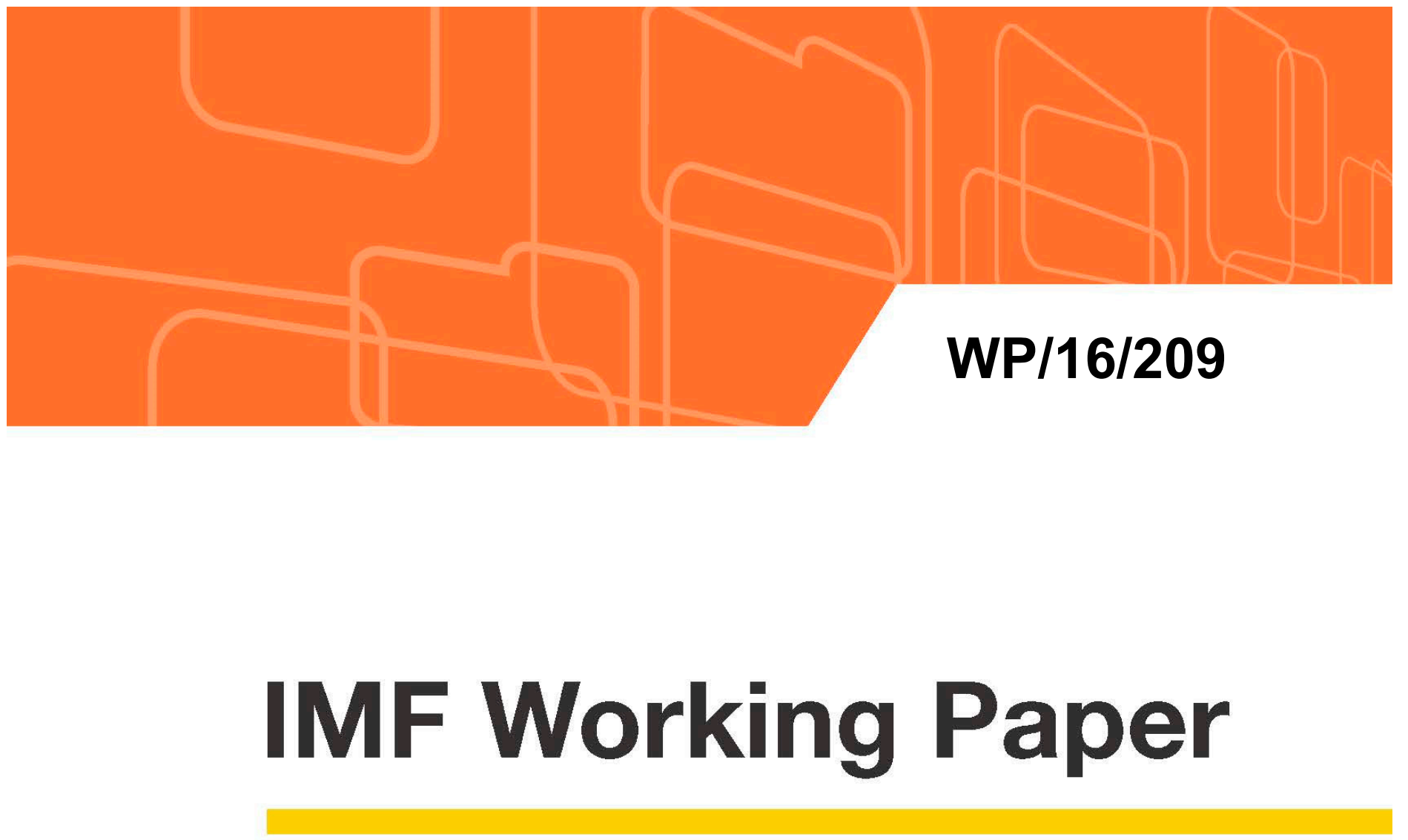

\title{
Can Statistical Capacity Building Help Reduce Procyclical Fiscal Policy in Developing Countries?
}

by Neree C.G.M. Noumon, Sampawende J.-A. Tapsoba, and Robert C. York

IMF Working Papers describe research in progress by the author(s) and are published to elicit comments and to encourage debate. The views expressed in IMF Working Papers are those of the author(s) and do not necessarily represent the views of the IMF, its Executive Board, or IMF management.

$$
\text { I N TER N A T | O N A L M O N E T A R Y F U N D }
$$




\title{
IMF Working Paper
}

\author{
Statistics Department
}

\section{Can Statistical Capacity Building Help Reduce Procyclical Fiscal Policy in Developing Countries?}

\author{
Prepared by Neree C.G.M. Noumon, Sampawende J.-A. Tapsoba, and Robert C. York ${ }^{1}$
}

November 2016

\section{IMF Working Papers describe research in progress by the author(s) and are published to} elicit comments and to encourage debate. The views expressed in IMF Working Papers are those of the author(s) and do not necessarily represent the views of the IMF, its Executive Board, or IMF management.

\begin{abstract}
Few papers have attempted to assess the role of "capacity," especially in the area of macroeconomic statistics. Consequently, we make an attempt to advance this literature through the construction of a "statistical capacity building index," and then test its explanatory power on the cyclicality of government spending. Using panel data from 62 developing countries, we find evidence that improvements in this index are associated with less procyclicality of government spending over the period 1990-2012; with the significance of this relationship dependent upon the quality of administrative and technical capacity of budgetary institutions.

JEL Classification Numbers: E02, E62, E32, H61, H68, C82

Keywords: Fiscal policy, Procyclicality, Capacity building, Budget institutions, Developing countries.

Author's E-Mail Address: nnoumon@imf.org; stapsoba@imf.org; ryork@imf.org

\footnotetext{
${ }^{1}$ The authors are grateful for the comments received from participants in a Statistics Department seminar where an earlier version of the paper was presented; and from Rasmané Ouedraogo, Mousse Ndoye Sow, René Tapsoba, Frederik Toscani, Nathaniel Arnold, Victor Lledo, Santiago Acosta, Francesco Luna, and Michele Andreolli.
} 


\section{Table of Contents}

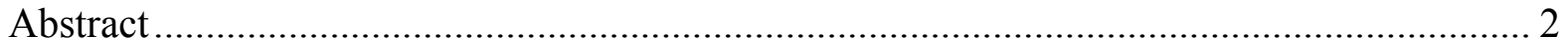

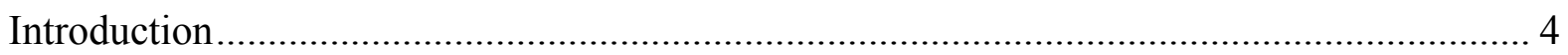

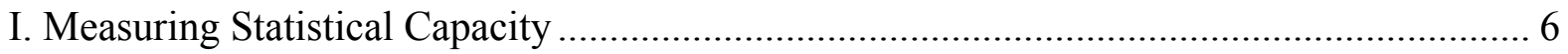

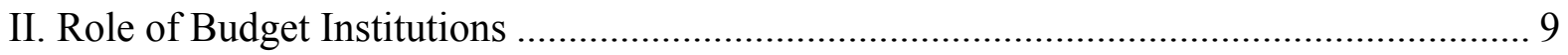

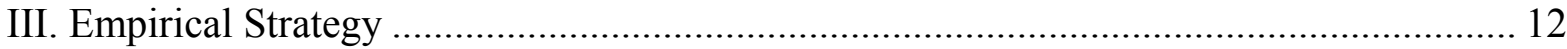

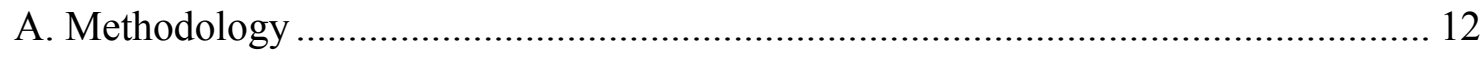

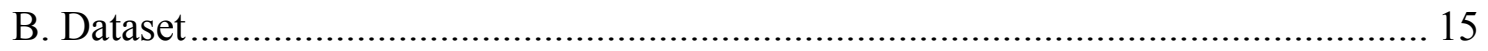

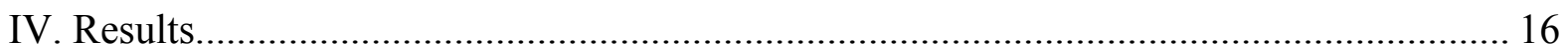

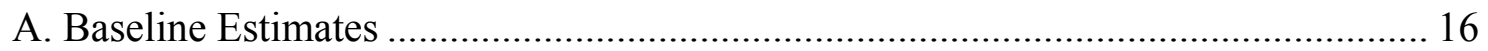

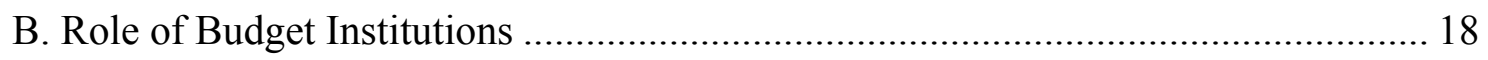

Budget institutions and the availability of better information .............................. 19

Budget institutions and the use of the information ............................................. 20

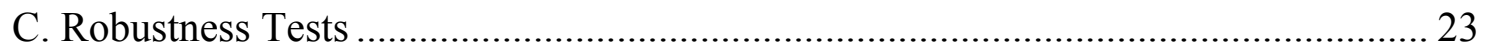

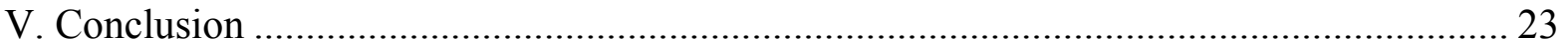

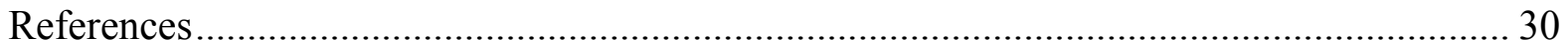

Tables

1. Statistical Capacity Building and Statistical Capacity ……..............................................

2. Summary Statistics of the Main Variables.......................................................................... 16

3. Statistical Capacity Building and the Procyclicality of Fiscal Policy (baseline)..................18

4. Statistical Capacity Building and the Budget Process .......................................................22

5. Robustness Analysis: Statistical Capacity Building and the Cyclicality of Fiscal Policy ...24

Figures

1. Evolution of Technical Assistance Delivery and Composition,1990-2012 ..........................

2. Statistical Capacity Building and Stages of the Budget.....................................................11

3. Statistical Capacity Building and the Quality of Budget Institutions ..................................11

Appendices

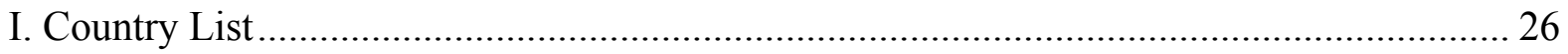

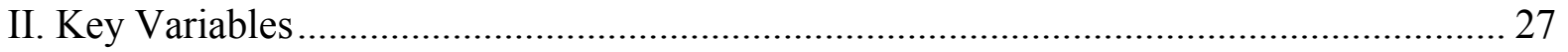

III. Granger Causality Tests Between Expenditure Growth and GDP Growth ...................... 28

IV. Different Dimensions of Budget Institutions............................................................... 29 


\section{INTRODUCTION}

The tendency for procyclicality of fiscal policies in developing countries is widespread and at odds with international best practices for effective macroeconomic management. The large empirical literature in this area generally attributes this tendency to institutional weaknesses and capital-market access issues. In particular, the lack of easy access to international capital markets during austere times supposedly forces these countries to refinance or repay, obliging them to undertake contractionary fiscal policies (Gavin and Perotti, 1997; Riascos and Végh, 2003; and Caballero and Krishnamurthy, 2004). Weak institutions are thought to encourage ineffective and often inappropriate spending of revenue windfalls, leaving countries with inadequate buffers to cope with adverse shocks (Tornell and Lane, 1998; Tornell, 1999; Talvi and Végh, 2005; Ilzetzki, 2007; and Alesina and others, 2008). The governance and "capacity" components of these institutional factors are, however, difficult to disentangle and our literature survey could not uncover empirical investigation into this issue.

Procyclical fiscal policies in developing countries might be further explained by poor forecasting performance, which could also be related to weak forecasting capacity caused by lack of data and technical expertise. Balassone and Kumar (2007), for instance, argue that lags in the formulation and implementation of the budget and difficulties to assess the state of the cycle could lead to such policies, along with weak institutions and lack of access to financial markets. Jonung and Larch (2006) and Leal and others (2008) show that errors for key macroeconomic parameters - in particular, growth and inflation - could lead to the inappropriate fiscal stance during the budget formulation, often resulting in procyclicality; and this factor has been reaffirmed more recently in the work of Lledo and PoplawskiRibeiro (2013).

It would appear obvious that good quality macroeconomic and financial statistics should play a strong role in assisting economic forecasts and policy formulation. From the fiscal side, for instance, public spending is likely to be more efficient if it is adequately planned and based on sound estimates of future government revenue, which are more likely to be the case if the revenue estimates are themselves, based on sound estimates of the economic activities that are taxed. More to the point, in the planning and negotiation phase of the budget process, understanding the economic conjuncture relies on national account statistics and their source data, which can often be of poor quality in developing countries. Hence, efforts to improve economic and budget forecasting and planning should probably go hand-in-hand with efforts to improve the quality of official statistics.

In this paper, we attempt to address the strength of the (potential) transmission channel through which better macroeconomic statistics could lead to less procyclical fiscal policies. We construct a statistical capacity building (SCB) index as a proxy for data quality improvements and use it to empirically assess this proposition. 
The argument is as follows. For capacity building to have an effect on data quality over time, it must affect the existing stock of capacity. We also explore the channels through which $\mathrm{SCB}$ affects fiscal procyclicality. In this context, we focus on the role played by the quality of existing budget institutions, which is widely cited as a factor that can influence fiscal discipline in developing countries (see for instance, Alesina and others, 2008; Dabla-Norris and others, 2010; Akitoby and others, 2006).

To our knowledge, the extensive literature on the cyclicality of fiscal policies in developing countries has not addressed this channel directly. Rather, the existing empirical literature has mainly focused on the link between statistical capacity improvement and the quality of economic forecasts (see for instance, Ley and Misch, 2014; and Mrkaic, 2010). Few studies, including Lledó and Poplawski-Ribeiro, 2013, and Leal and others, 2008, have tried to establish a link between forecast accuracy and budget outcomes and performance.

To construct our SCB index, we rely mostly on data supplied by the IMF's Statistics Department concerning technical assistance (TA) provided to member countries on macroeconomic statistics and budgetary forecasting, in particular. The collection of this data follows a standard procedure making them comparable across countries. We focus on TA relevant to budgetary forecast including TA on national account statistics, prices, government finance, and monetary and financial statistics: all of the data needed to prepare high quality fiscal forecasts and support optimal policy outcomes.

Using our SCB index and empirical model we obtain two key results. First, we find evidence that SCB increases statistical capacity and can lead to a statistically-significant reduction in fiscal procyclicality in developing countries. This effect appears robust to various specifications of the SCB index and to its effectiveness across different sub-group of those countries. Second, we find that the effect of statistical capacity building also depends on the quality of budget institutions and is stronger for: (1) countries with room to improve budget institutions through increased information sharing (e.g., planning, transparency, credibility and sustainability); and (2) countries with adequate budget processes including transparent approval, implementation, and rules and controls. In these cases, statistical capacity building could lead an improvement in the execution of fiscal policy.

The remainder of the paper is organized as follows. Section II presents the design and construction of our SCB index. Section III details the empirical model and the dataset. Section IV elaborates on the estimation results. Section V concludes and provides a few policy implications. 


\section{Measuring Statistical Capacity}

Statistical capacity and capacity building are somewhat different but related concepts. We could consider statistical capacity as a set of skills, knowledge, and infrastructure needed for the compilation, maintenance, and dissemination of high quality data. In this sense, it could be considered as the stock of statistical capacity that could be upgraded over time through many channels including TA and training. In this paper, we refer to TA and training as "statistical capacity building," or the flow that builds up the stock of capacity. Indeed, the primary focus of our empirical analysis is on the particular role played by TA in reducing procyclicality of fiscal policies in developing countries. We focus on TA for two main reasons: (1) such assistance represents more than 85 percent of the Fund's statistical capacity building activities, and (2) because it can be targeted to specific needs, it could have a more effective impact on resolving budgetary-related capacity issues than more general training programs. In general, a SCB measure should take into account initiatives aimed at increasing the stock of statistical capacity on a broad basis. However, since we are interested in the specific question of cyclical fiscal policy, we limit the scope of SCB to TA directed toward improving fiscal forecasting and the quality (including periodicity and timeliness) and coverage of important macroeconomic variables, like growth and inflation. Accordingly, we focus on IMF TA in the statistical area that covers national accounts (NAS), prices (PR), monetary and financial statistics (MFS), and government finance statistics (GFS). Indeed, National Accounts statistics form the basis for computing and forecasting growth, monetary and prices statistic are the main inflation forecast. Similarly, GFS data help to present fiscal information in way that could facilitate policy making. Thus, we posit that this TA leads to better data quality and consequently, improved budgetary forecast performance and less procyclicality.

To construct the SCB index, we use country-specific and regional-level data on the number of TA activities (so-called missions) provided to developing countries over the period 1990-2012. ${ }^{2}$ To our knowledge, this data and approach has not been previously used to assess the potential impact of SCB on fiscal policies. Data on the IMF's statistical TA missions are taken from the IMF's internal TA Information Management System (TAIMS), which records documents related to TA projects undertaken by the IMF Statistics Department. TAIMS allows for the conduct of efficient and comprehensive evaluation of TA delivery: it classifies missions according to the beneficiary country or region, date, duration, and includes other useful characteristics. The system also records an entry for each team member of a given TA mission. In this paper, we only account for the number of missions and do not consider the size of the team delivering it. Accordingly, we compute the number of TA missions based on the unique mission identifiers. In the construction of the SCB index, regional missions are treated as a series of country-specific missions to each country in the considered region. As a result, we expect to see a significant rise in the index, after the shift of the IMF's TA strategy to a more

\footnotetext{
${ }^{2}$ We define regional TA by TA provided to groups of countries, usually regions. Most regional TA missions are delivered by Regional Technical Assistance Centers (RTAC). A country-specific mission is a mission delivered to single country.
} 
regional approach in the early 2000s (following the introduction of the RTACs). ${ }^{3}$ It is worth noting that this study does not consider technical assistance in fiscal areas such as expenditure policy, public finance management, and tax Policy. Although these areas of TA could improve fiscal outcomes by upgrading countries' capacity to forecast and implement policies, the focus of this study is on the impact of data quality on fiscal outcome. Finally, the concept of statistical capacity captured by our SCB index is limited to the "skills and knowledge" aspect, and does not include infrastructures — also part of the broader definition of capacity. ${ }^{4}$

In practice, we aggregate the four dimensions of the Statistics Department's activities (i.e., NAS, PR, MFS, and GFS) allocating identical weights to reflect the equal importance of macroeconomic (i.e., output and inflation) and budget-specific factors (or variables) in affecting fiscal forecasting. This hypothesis is premised on the notion that TA missions are substitutable in their impact on the cyclicality of fiscal policy. For each country $i$, and year $t$, the index of SCB $\left(S C B_{i t}\right)$ is defined as the sum of the number of TA missions received for the four dimensions. Using this construction, we are able to cover 62 developing countries (Appendix I). The SCB index rapidly increased starting in early 2000s, reaching its highest level during 2004-06, before falling after 2007 (Figure 1, Panel A). The bulk of macroeconomic statistics went to developing countries considered in the paper. In most years, less than half of total TA received by these countries is considered in the construction of our SCB index (Figure 1, Panel B). The decomposition of this index by type of macroeconomic statistic reveals that NA and GFS have the most prominent shares (Figure 1, Panel B). In Figure 1, Panel D, the surge in SCB starting in the early 2000s is substantially driven by the shift to a more regional approach to TA delivery through the introduction of Regional TA Centers (RTACs) and the resulting expansion in the number of short- and longterm expert assignments. The decline in TA delivery during 2007-09 was related to a number of factors including the downsizing of the Fund during this period, and a general reduction of the IMF's Statistic Department resources and staffing available to deliver TA (as reported in STA's business plan).

For capacity building to have an effect on data quality over time, it must affect the existing "capacity stock." We empirically assess the relationship between statistical capacity (SC) and $\mathrm{SCB}$, to provide the justification - or rather causal link - as to why SCB could translate into better fiscal outcomes. Using the World Bank's capacity index, the causality running from SCB to statistical capacity is assessed though a panel regression over the period 1990-2012, after controlling for lagged GDP per capita, and cumulative years under IMF programs. The

\footnotetext{
${ }^{3}$ It should be highlighted that over this period, the IMF greatly accelerated its TA in many areas with the creation of a number of Regional TA Centers (RTACs, funded by donors), which allowed the delivery of better targeted and more frequent missions and closer coordination and cooperation with other TA providers. The RTACs also enhanced the Fund's ability to respond quickly to emerging demands and needs.

${ }^{4}$ In future, available cross-country and comparable data on statistical infrastructure would help improve the index.
} 
lagged effect of SCB on statistical capacity is significant and positive (Table 1) and supports our assumption that SCB does increase SC. This result is unchanged when we assess the effect of the cumulative SCB (CSCB) on capacity building (Table 1, columns (3), (4), (7), and (8)). This initial finding suggests that TA leads to an increase in the quality of the data available for the purpose of producing fiscal forecasts, and, therefore could lead to better fiscal outcomes. We formally show below that statistical capacity building could reduce profligate spending.

Figure 1. Evolution of Technical Assistance Delivery and Composition, 1990-2012
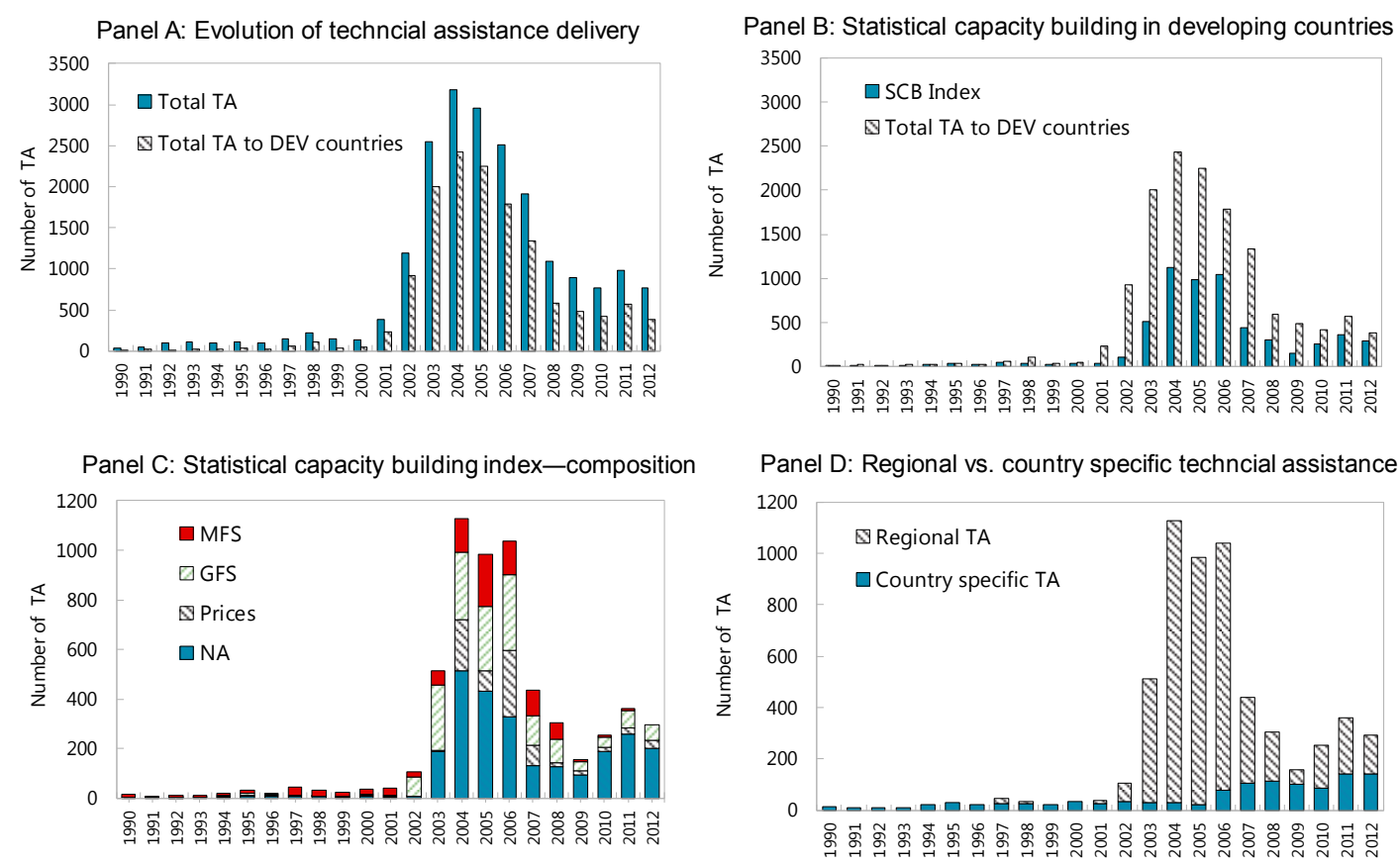

Source: IMF Statistics Department and authors' calculations.

Note: MFS refers to Monetary and Financial Statistics, GFS to Government Finance Statistics, and NA to National Accounts statistics. 
Table 1. Statistical Capacity Building and Statistical Capacity

\begin{tabular}{|c|c|c|c|c|c|c|c|c|}
\hline \multirow{2}{*}{$\begin{array}{l}\text { Dependent variable } \\
\text { Within fixed-effect (FE) estimates }\end{array}$} & \multicolumn{4}{|c|}{ WBSC, overall } & \multicolumn{4}{|c|}{ WBSC, timeliness and frequency } \\
\hline & $(1)$ & $(2)$ & (3) & $(4)$ & (5) & (6) & $(7)$ & (8) \\
\hline \multirow[t]{2}{*}{ SCB index, lagged } & $0.10^{* * *}$ & $0.10^{* * *}$ & & & $0.15^{* * *}$ & $0.15^{* * *}$ & & \\
\hline & $(0.04)$ & $(0.04)$ & & & $(0.03)$ & $(0.03)$ & & \\
\hline \multirow[t]{2}{*}{ Log CSCB index, lagged } & & & $0.93^{*}$ & $0.93^{*}$ & & & $1.62^{* * *}$ & $1.60^{* * *}$ \\
\hline & & & -0.55 & -0.55 & & & -0.41 & -0.41 \\
\hline \multirow[t]{2}{*}{ Log per capita GDP, lagged } & $7.83^{* \star *}$ & $7.83^{* \star *}$ & $5.67^{\star \star *}$ & $5.67^{* \star \star}$ & $8.44^{\star * \star}$ & 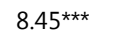 & $4.92^{* \star *}$ & $4.94^{\star * \star}$ \\
\hline & $(1.31)$ & $(1.31)$ & $(1.60)$ & $(1.60)$ & $(0.98)$ & $(0.99)$ & (1.46) & $(1.47)$ \\
\hline \multirow[t]{2}{*}{ Program, lagged } & & 0.01 & & -0.23 & & -0.47 & & -0.63 \\
\hline & & $(0.76)$ & & $(0.74)$ & & $(0.71)$ & & $(0.68)$ \\
\hline \multirow[t]{2}{*}{ Constant } & 8.54 & 8.54 & $21.79 * \star$ & $21.79 * \star$ & $23.40^{\star \star \star}$ & $23.46^{\star \star \star}$ & $42.97^{\star \star \star}$ & $42.98^{\star * *}$ \\
\hline & $(8.77)$ & $(8.78)$ & $(9.67)$ & $(9.70)$ & $(6.60)$ & $(6.65)$ & $(8.91)$ & $(9.01)$ \\
\hline Observations & 557 & 557 & 605 & 605 & 557 & 557 & 605 & 605 \\
\hline R-squared & 0.21 & 0.21 & 0.19 & 0.20 & 0.28 & 0.28 & 0.27 & 0.27 \\
\hline Number of countries & 62 & 62 & 62 & 62 & 62 & 62 & 62 & 62 \\
\hline
\end{tabular}

\section{Role OF BUdGet InSTITUTIONS}

Identifying the channels and conditions through which SCB affects cyclical fiscal policy would help to design policies aimed at tackling fiscal profligacy. We specifically investigate the role played by the quality of existing budget institutions and their interaction with SCB in mitigating the effect of procyclical public spending. Following Dabla-Norris and others (2010), we define "budget institutions" broadly to include formal and informal budgetary rules and procedures governing budget planning (also including negotiation), approval, and implementation. We also use indices of institutional quality provided in the database from the same authors. ${ }^{5}$ The dataset records the quality of budget institutions along two dimensions (see Appendix II). The first dimension covers the various stages in the budget process (planning, approval, and implementation), while the second dimension reflects various characteristics of the budget process (the degree of centralization of budgetary decisionmaking; the existence and effectiveness of rules and controls; the sustainability and credibility of the budget as a key policy instrument; and its comprehensiveness and transparency).

\footnotetext{
${ }^{5}$ As a result of using Dabla-Norris and others' data to refine the baseline results, the sample size is reduced to 41 from 62 countries.
} 
The channels through which the quality of budget institutions might influence the effectiveness of SCB in reducing procyclicality are twofold. First, SCB could help increase the amount and quality of available information and improve fiscal forecasts; and better fiscal forecasts would enhance budget planning and negotiation (i.e., allocation of the budget among the government's priorities). This view is elaborated in the scatter plot of the SCB index against the planning and negotiation score (Figure 2). We would expect, ex ante, that countries with weak performance in the planning and negotiation phase to benefit from SCB in terms of a larger reduction in procyclicality.

Second, a strong linear relationship between planning and implementation can be seen in Figure 2 (right-hand side panel), which plots the distribution of countries in the planningimplementation space delineated in four quadrants by planning and implementation performance above and below the median. It appears that only 9 countries are outside the quadrants strong planning-strong implementation and weak planning and negotiation-weak implementation. This suggests that good planning and negotiation are associated with good implementation in our sample. This association between planning and implementation is likely to be causal as corroborated by many studies linking fiscal forecasts and fiscal outcomes (e.g., Lledo and Poplawski-Ribeiro, 2013). Intuitively, the implementation phase of the budget is based on forecasts from the planning and negotiation phase of the budget. Therefore, good planning and negotiation will tend to be associated with good implementation. Thus the effect of SCB in terms of overall improvement in the budget process will probably depend on countries' performance in different stages. In particular, the effective use of better data in the implementation stage is important to reap the potential benefits of SCB in reducing fiscal procyclicality.

Two groups emerge from our analysis of the relationship between budget institutions and statistical capacity building. One group of budget institutions exhibit a positive relation with the SCB while the second group exhibits a weak correlation (Figure 3). On the one hand, budget institutions exhibiting positive correlation with SCB (planning, transparency, centrality, comprehensiveness, sustainability and credibility of the budget) also coincide with the group of budget dimensions that could improve with information. On the other hand, budget institutions with weak correlation with SCB coincide with aspects of budget institutions (approval, implementation, rules and control) that, when well established, tend to make a better use of existing information.

More generally, we should expect to have a more pronounced effect for weak performers in the first group of budget institutions which are likely to be improved by SCB and translate into better fiscal outcomes. With regards to the second group, countries with strong performance are expected to experience a greater benefit, as they are likely to make better use of the improved information that come with better statistics. 
Figure 2. Statistical Capacity Building and Stages of the Budget

Panel A. Budget planning and negotiation vs. SCB

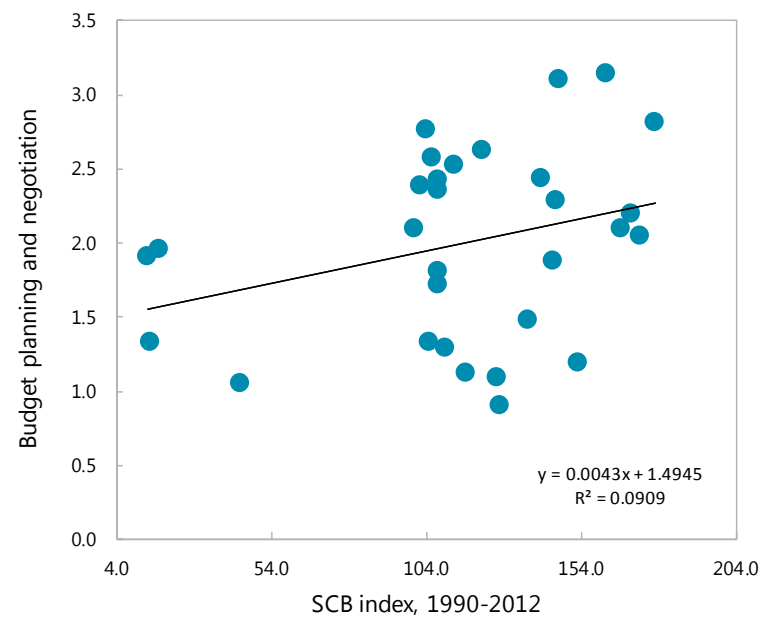

Panel B. Budget planning vs. budget implementation

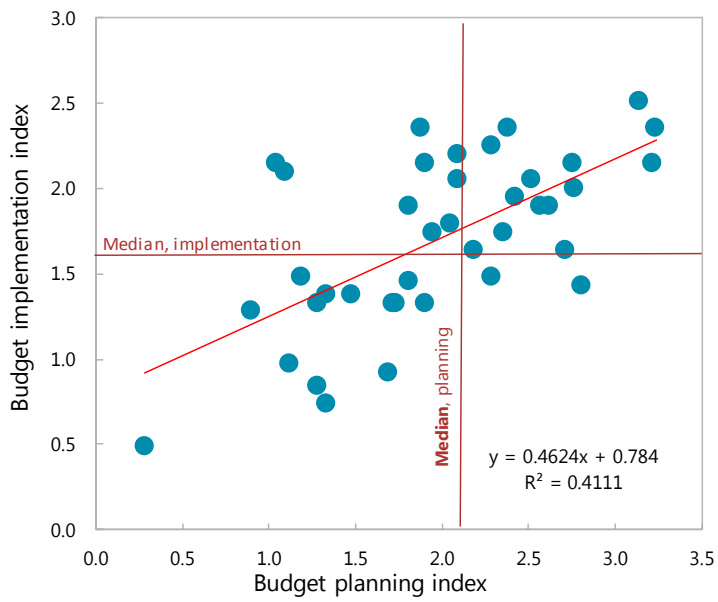

Source: IMF's Statistics Department and authors' calculations.

Note: SCB refers to statistical capacity building.

\section{Figure 3. Statistical Capacity Building and the Quality of Budget Institutions}
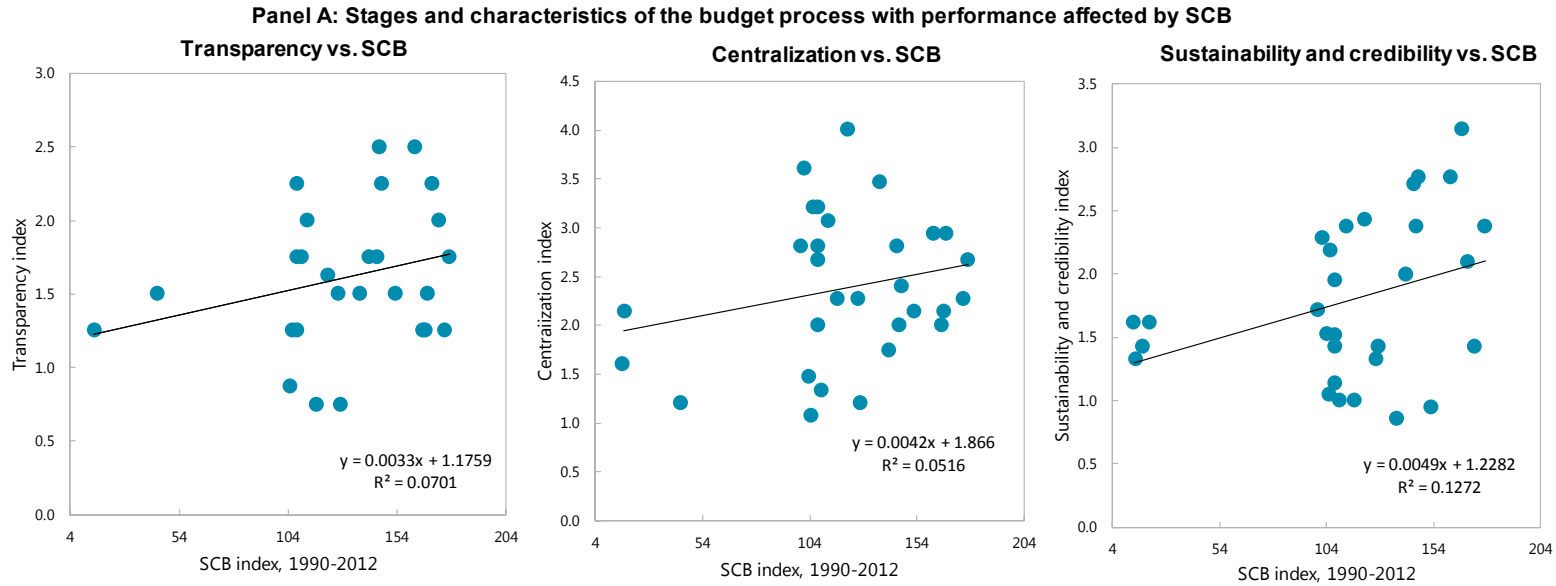

Panel B: Stages and characteristics of the budget process with performance not directly affected by SCB
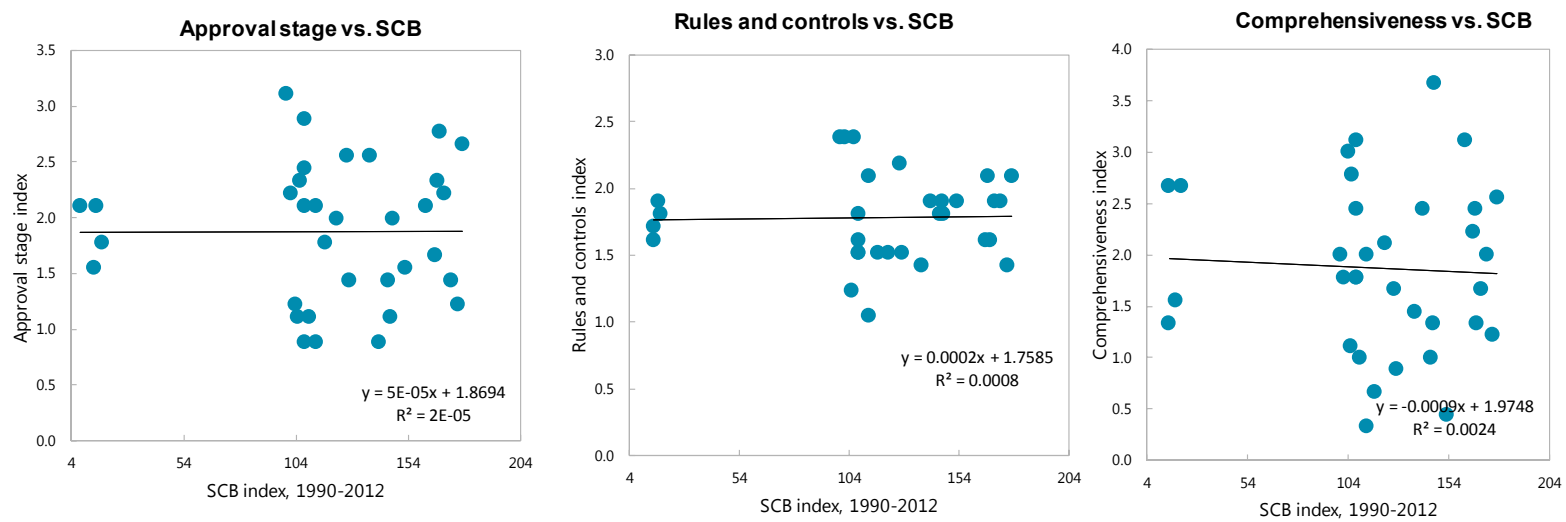

Source: IMF's Statistics Departement and authors' calculations. Note: SCB stands for statistical capacity building. 


\section{EMPIRICAL STRATEGY}

\section{A. Methodology}

An extensive empirical literature on assessing the cyclicality of fiscal policies exists, which we broadly follow in our approach (see for instance, Talvi and Végh, 2005; Ilzetzki and Végh, 2008; and Alesina and others, 2008). This empirical literature suggests estimating a fiscal reaction function of the following general form:

$g_{i, t}=\alpha+\beta y_{i, t}+\gamma g_{i, t-1}+X_{i, t}^{\prime} \delta+v_{i, t}$

where $i$ and $t$ represent country and period, respectively; $g_{i, t}$ is an indicator of fiscal policy defined, for instance, in terms of the fiscal balance as share of GDP or total government expenditure; $y_{i, t}$ is the output cycle represented as the output gap; $X_{i, t}^{\prime}$ is a vector of control variables; and $v_{i, t}$, the disturbance term, which captures fiscal shocks. The disturbance term is the sum of three orthogonal components: country fixed effects $n_{i}$, period fixed effects $u_{t}$, and idiosyncratic fiscal shocks $\xi_{i, t}\left(v_{i, t}=n_{i}+u_{t}+\xi_{i, t}\right)$. This lag is included to ensure longterm mean reversion in government consumption, which is consistent with long-term fiscal sustainability. In equation (1), the coefficient $\beta$ captures the short-term overall cyclical behavior of government spending without differentiating between discretionary fiscal actions from those arising from automatic stabilizers, responding to the economic cycle. While a few authors use the fiscal balance as the dependent variable in equation (1) the majority of studies focus on the growth or level of public spending when testing for cyclicality, especially in developing countries where automatic stabilizers are likely to be small (Kaminsky, Reinhart, and Végh 2004). ${ }^{6}$ Under this approach, a change in government expenditure might be considered as a reasonable approximation of discretionary fiscal policy. The cyclicality of fiscal policy is then determined by looking at the sign and the size of the coefficient $\beta$. When the indicator of fiscal policy is expressed in terms of government expenditure, procyclicality is assumed in the data if $\beta>0$, i.e., a cyclical upturn (downturn) is associated with an increase (decrease) in government spending; countercyclical if $\beta<0$; and acyclical if

\footnotetext{
${ }^{6}$ It should be noted that Kaminsky, Reinhart, and Végh (2004) among others have questioned the accuracy of fiscal balance indicators in assessing the cyclicality of the fiscal stance, mainly on two grounds. First, the fiscal balance and other indicators like the revenue- and expenditure-to-GDP ratios reflect the outcomes of policy and are affected only endogenously by the actions of policymakers. For this reason, the direction of co-movements between these fiscal indicators and economic cycles might be ambiguous. Second, expressing fiscal variables as proportions of output could yield misleading results because the cyclical fiscal stance may be dominated by the cyclical behavior of output.
} 
$\beta=0$. The fiscal reaction function can be reformulated as a Taylor-type rule without the inflation terms.

$$
\left(G_{i, t}-G_{i, t}^{*}\right)=\alpha+\beta\left(Y_{i, t-1}-Y_{i, t-1}^{*}\right)+\gamma\left(G_{i, t-1}-G_{i, t-1}^{*}\right)+X_{i, t}^{\prime} \delta+v_{i, t}
$$

where the superscript * denotes the long-run levels of the variables, $\left(G_{i, t}-G_{i, t}^{*}\right)$ the deviation of actual government spending from its long-run trend, $\left(Y_{i, t}-Y_{i, t}^{*}\right)$ the deviation of real output from its long-term trend, and $\beta$ captures the short-run fiscal response to the economic cycle. As advocated by Kaminsky, Reinhart, and Végh (2004) the reaction function in equation (2) is formulated in terms of co-movements between spending and economic cycles, and not in terms of fiscal balance indicators. Estimating equation (2) requires a measure of the unobserved long-run values of government spending and output. One approach would be to use a dynamic equation and run the regression in first difference (as in Lane, 2003 and Thornton, 2008, and Lledo and others, 2011), with the lagged values of government spending or using the growth rate of the different variables. This formulation yields equation (3), which we adopt as our baseline model:

$G_{i, t}^{g}=\alpha+\beta Y_{i, t}^{g}+\gamma G_{i, t-1}^{g}+X_{i, t}^{\prime} \delta+v_{i, t}$

$G_{i, t}^{g}$ and $Y_{i, t}^{g}$ denote growth in spending and output, respectively. The coefficient $\beta$ is expressed as the first derivative of growth in spending with respect to growth in output (i.e., $\left.\partial G_{i, t}^{g} / \partial Y_{i, t}^{g}=\beta\right)$; the coefficient $\gamma$ captures possible inertia effects and is expected to be less than 1 , in absolute value terms. ${ }^{7}$ To investigate the separate influence of statistical capacity building on fiscal procyclicality, we model the cyclicality parameter, $\beta$, to depend on the set of control variables and the SC index denoted by SCB, that is ${ }^{8}$

$$
\beta_{i, t}=\partial G_{i, t}^{g} / \partial Y_{i, t}^{g}=\beta_{0}+X_{i, t}^{\prime} \beta_{1}+\beta_{2} S C B_{i, t}
$$

Consequently, the impact of SCB on the cyclicality coefficient $\beta$, is given by the coefficient $\beta_{2}$, which measures the marginal impact of the index SCB on cyclicality, i.e., $(\partial \beta / \partial S C B)$. SCB would affect the cyclicality of fiscal policies if - after controlling for financing constraints and institutions - the coefficient $\beta_{2}$, remains statistically significant; in particular,

\footnotetext{
${ }^{7}$ For a given time series process $k_{t}=\gamma k_{t-1}$ or equivalently $\Delta k_{t}=\gamma \Delta k_{t-1}$, mean reversion implies that $|\gamma|<1$. The series will either oscillate around the mean or drift away from the mean unless $|\gamma|<1$.

${ }^{8}$ In Equation (4), the cyclicality coefficient depends on time and the country.
} 
a negative sign for $\beta_{2}$ would imply that SCB would lead to a reduction in the level of cyclicality. Substituting equation (4) into equation (3), yields equation (5), in which the cyclicality coefficient - the coefficient of $Y_{i, t}^{g}$ - is a linear function of control variables and $\mathrm{SC}$.

$G_{i, t}^{g}=\alpha+\left(\beta_{0}+X_{i, t}^{\prime} \beta_{1}+\beta_{2} S C B_{i, t}\right) Y_{i, t}^{g}+\gamma G_{i, t-1}^{g}+X_{i, t}^{\prime} \delta+v_{i, t}$

By expanding and rearranging the terms in equation (5) we obtain equation (6), which contains two sets of interactive terms. The first set of interactions $X_{i, t}^{\prime} * Y_{i, t}^{g}$, includes financing constraints and institutions and the second set of interactions consists of the crossterm of $Y_{i, t}^{g}$ with the SCB index developed in Section II above.

$G_{i, t}^{g}=\alpha+\beta_{0} Y_{i, t}^{g}+X_{i, t}^{\prime} * Y_{i, t}^{g} \beta_{1}+\beta_{2} Y_{i, t}^{g} * S C B_{i, t}+\gamma G_{i, t-1}^{g}+X_{i, t}^{\prime} \delta+v_{i, t}$

Admittedly, estimating equation (6) poses several challenges because of the potential endogeneity. The main challenge is the potential for reverse causality between public expenditure and output, since output is likely to be responsive to a fiscal stimulus/contraction as conveyed in the standard neo-Keynesian model. Moreover, the lagged-dependent variable is correlated with the error terms, leading to the well-known Nickel (1981) bias. An additional challenge is the possibility that some omitted variables may be correlated with public expenditure and output.

For this reason, our preferred estimates are based on the within fixed-effect estimator with year fixed effect, which mitigate the simultaneity and omitted variables biases by controlling for time-invariant idiosyncratic factors. We believe that the endogeneity is less of a problem if the simultaneity and omitted variables biases are accounted for. We therefore mostly focus on fixed effect estimates in the rest of the paper. We present the results with and without the lagged dependent variable to assess the extent of the so-called Nickel bias discussed above. Furthermore, to assess the relevance of the reverse causality, we assess the direction of the causality between aggregate expenditures and output using the Granger-causality test (Appendix II). Finally, to produce robust results autocorrelation and heteroskedasticity are corrected for. As robustness check, we present results using GMM. Indeed, to address endogeneity issues, the empirical literature has often used the generalized method of moments (GMM), which is particularly adapted for dynamic panels. However, the GMM technique is very sensitive to the risk of proliferation of instruments, which are more pronounced when splitting the sample or including interaction terms as done later in this paper. Indeed, depending on the lags chosen, the number of instruments can be larger than the cross-sectional dimension and create an over-identification bias. 


\section{B. Dataset}

To carry out the analysis, we use data from the IMF's World Economic Outlook (WEO) database for general government total expenditure and the GDP deflator over the period 1990-2012 (see Appendix III for the sources of the variables; and Table 2 for summary statistics). The sample period was selected to reflect the intensity of the IMF's TA in statistics, which had picked up markedly after 1990. Public expenditure and GDP data are converted into real terms using the GDP deflator. The dataset covers 62 developing countries, based on data availability. We also rely on the World Bank's statistical capacity database, which is extracted from the World Bank Statistical Capacity website and contains country scores for the overall statistical capacity and for three categories (Methodology, Source Data, and Periodicity). ${ }^{9}$ The website provides information on various aspects of developing countries' national statistical systems.

Following the literature, we control for the effect of institutions and financing constraints on procyclicality. We measure institutions by a normalized version of the Polity2 score from the Polity IV Project database (Marshall and Jaggers, 2002), which is by far the most popular and well-accepted measure of a country's political regime. The index subtracts the country's score in an "Autocracy" index from its score in a "Democracy" index to generate an aggregate democracy variable that runs from -10 to 10 . To proxy for the degree of financial constraints facing a country's government, we compute the ratio of aid-to-GDP using data on gross official development aid assistance received from the World Development Indicators (WDI) database. Indeed, aid inflows are a good approximation of financing constraints of fiscal policy in developing countries (Pallage and Robe, 2001; Guillaumont and Tapsoba, 2012). Other measures, such as integration in international capital markets and financial depth, are less relevant in the case of developing countries.

\footnotetext{
${ }^{9}$ http://datatopics.worldbank.org/statisticalcapacity/.
} 
Table 2. Summary Statistics of the Main Variables

\begin{tabular}{lrrrrr}
\hline Variable & Observations & Mean & Std. dev. & Min. & Max. \\
\hline Real GDP growth & 1343 & 4.0 & 5.7 & -41.9 & 62.2 \\
Government expenditure growth & 1097 & 6.3 & 15.7 & -61.8 & 132.6 \\
Polity 2 & 1418 & 1.4 & 5.7 & -10.0 & 10.0 \\
Aid (percent of GDP) & 1408 & 10.4 & 11.7 & -0.2 & 147.2 \\
Statistical Capacity building index & 1426 & 4.1 & 7.4 & 0 & 33 \\
World Bank's Statiscal Capacity Index (WBSC) & 614 & 62.8 & 14.5 & 16.7 & 94.4 \\
IMF program & 1426 & 0.2 & 0.4 & 0.0 & 1.0 \\
Budget institutions & & & & & \\
$\quad$ Planning and negotiation stage & 41 & 2.0 & 0.7 & 0.3 & 3.2 \\
$\quad$ Approval stage & 41 & 1.9 & 0.7 & 0.9 & 3.2 \\
$\quad$ Implementation stage & 41 & 1.7 & 0.5 & 0.5 & 2.5 \\
$\quad$ Fiscal transparency & 41 & 1.8 & 0.6 & 0.4 & 2.5 \\
$\quad$ Rules and controls & 41 & 1.8 & 0.5 & 0.3 & 2.7 \\
$\quad$ Comprehensiveness of the budget & 41 & 1.9 & 0.8 & 0.3 & 3.7 \\
$\quad$ Centralization of the budget & 41 & 2.4 & 0.8 & 0.4 & 4.0 \\
$\quad$ Sustainability and credibility of the budget & 41 & 1.7 & 0.7 & 0.2 & 3.1 \\
\hline
\end{tabular}

Source: Text Section B (data description) and Appendix II.

\section{Results}

\section{A. Baseline Estimates}

As stated above, the main sources of endogeneity in our estimations stem from the potential growth-spending reverse causality and the inclusion of the lagged dependent variable. The extent of endogeneity for the first source is assessed through a "precedence" test, which also indicates the direction of causality between growth and spending (Appendix II). For each country, we use the classic Akaike (AIC), Hannan-Quinn (HQIC), and Schwarz (SBIC) information criteria to determine the optimal lag to use in the causality test. ${ }^{10} \mathrm{We}$ find that the optimal lag length is 1 and no evidence of a reverse causality from expenditure to output. The second source of bias - the Nickel bias - is gauged by comparing the fixed-effect estimates with and without the lagged dependent variable. In Table 3 columns (1) and (2), these estimates are approximately the same suggesting that we do not lose much by omitting the lagged dependent variable.

Since we determine that endogeneity issues are have limited effects, we avoid the "instruments proliferation" issue and estimate equation (6) using the within fixed effect estimator. To further control for omitted variable bias, we also include additively our measure of institution and access to finance in equation (6). Results are reported in Table 3. The procyclicality of government spending in developing countries is verified. Across the

\footnotetext{
${ }^{10}$ Given the unique sample considered, the test results should be interpreted as a temporal precedence test rather than economic causality.
} 
estimates, spending overreacts to the cycle more than proportionally; i.e., $\beta>1$ and is statistically significant. A one percentage point increase in output growth leads to about 1.5 percentage point increase in public spending in real terms (Table 3, column (3)). When included, the coefficient associated with the lagged dependent variable is lower than 1 in absolute term, suggesting a convergence process, though modest, in the growth of public spending. Our results are preserved when the sample is stops in 2008 or in 2010, suggesting that our findings are not driven by data revision.

As postulated above, SCB is a determining and significant factor of fiscal procyclicality. In each estimate, the coefficient on the interaction between the SCB proxies and GDP growth are negative and significant. SCB helps reduce fiscal procyclicality, after controlling for empirically important drivers of public spending: namely financial constraints and institutional quality (Table 3). All other things being equal, receiving an additional "unit of TA" is associated with a reduction of the procyclicality bias by about 3 percent with the coefficient $\beta$ decreasing from 1.0 to 0.97 .

The control variables have the expected signs. Public spending is sensitive to net aid inflows in developing countries. The estimated coefficients are statistically significant. A 1 percent increase in aid-to-GDP ratio leads to an increase in growth of public expenditure by 0.3 to 0.4 percentage points. Consistent with the existing literature, the coefficient on the cross product of aid-to-GDP growth is positive and statistically significant. An increase of 10 percent in aid-to-GDP leads to a worsening of the procyclicality of real government expenditure by about 0.1 , with the reaction coefficient $\beta$, moving slightly from 1.0 to 1.1 . In the literature, aid disbursements are found to have a procyclical influence on fiscal policies and often increase during expansion episodes and decline in recessions, contributing to this phenomenon (Pallage and Robe, 2001 and Guillaumont and Tapsoba, 2012). Similarly, the effect of the institution variable is line with the literature but not significant. Countries with democratic institutions tend to have larger growth in real government spending. The coefficient on the cross product for institutions is negative and provides support to the dampening effect of democratic institutions on the procyclicality of public spending (Frankel and others 2013 and Alesina and others, 2008). 
Table 3. Statistical Capacity Building and the Procyclicality of Fiscal Policy (baseline)

\begin{tabular}{|c|c|c|c|c|}
\hline \multicolumn{5}{|c|}{ Dependent variable: Growth in government expenditure } \\
\hline & \multicolumn{2}{|c|}{$\begin{array}{c}\text { Within fixed-effect (FE) } \\
\text { estimates, with year } \\
\text { dummies }\end{array}$} & \multicolumn{2}{|c|}{$\begin{array}{c}\text { Dynamic panel (system GMM) } \\
\text { estimates }\end{array}$} \\
\hline & & & Whole sample & $1992-2008$ \\
\hline & (1) & (2) & (3) & (4) \\
\hline \multirow{2}{*}{ Expenditure growth, lagged } & & $-0.11^{*}$ & 0.11 & 0.10 \\
\hline & & $(0.06)$ & $(0.09)$ & $(0.12)$ \\
\hline \multirow[t]{2}{*}{ GDP growth } & $1.00^{\star * *}$ & $0.91^{* * *}$ & $1.06^{\star *}$ & 0.90 \\
\hline & $(0.14)$ & $(0.15)$ & $(0.46)$ & $(0.56)$ \\
\hline \multirow[t]{2}{*}{ Combined Polity Score (Polity2) } & 0.18 & 0.02 & -0.00 & -0.10 \\
\hline & $(0.21)$ & $(0.22)$ & $(0.14)$ & $(0.20)$ \\
\hline \multirow[t]{2}{*}{ Aid-to-GDP ratio } & $0.36^{* \star *}$ & $0.39^{* * *}$ & $0.21^{* *}$ & $0.23^{* *}$ \\
\hline & $(0.09)$ & $(0.08)$ & $(0.09)$ & $(0.11)$ \\
\hline \multirow[t]{2}{*}{ GDP growth * Polity2 } & 0.00 & 0.02 & 0.00 & 0.02 \\
\hline & $(0.02)$ & $(0.02)$ & $(0.03)$ & $(0.03)$ \\
\hline \multirow[t]{2}{*}{ GDP growth * Aid-to-GDP ratio } & $0.01^{* \star *}$ & $0.01^{* \star *}$ & 0.01 & 0.01 \\
\hline & $(0.00)$ & $(0.00)$ & $(0.01)$ & $(0.01)$ \\
\hline \multirow[t]{2}{*}{ GDP growth * SCB } & $-0.03^{* *}$ & $-0.03^{* *}$ & $-0.03^{* *}$ & $-0.03^{* *}$ \\
\hline & $(0.01)$ & $(0.01)$ & $(0.01)$ & $(0.02)$ \\
\hline \multirow[t]{2}{*}{ Constant } & 1.19 & 2.14 & -0.55 & -0.38 \\
\hline & $(2.01)$ & $(2.13)$ & $(2.16)$ & $(2.44)$ \\
\hline Number of observations & 1,096 & 1,035 & 1,035 & 787 \\
\hline R-squared & 0.181 & 0.179 & & \\
\hline Number of countries & 62 & 62 & 62 & 61 \\
\hline Hansen test $p$-value & & & 0.52 & 0.36 \\
\hline $\operatorname{AR}(1)$ & & & 0.00 & 0.00 \\
\hline $\mathrm{AR}(2)$ & & & 0.73 & 0.79 \\
\hline Number of instruments & & & 64 & 52 \\
\hline
\end{tabular}

\section{B. Role of Budget Institutions}

Now that we have established a statistically significant link between SCB and fiscal procyclicality, we explore the transmission channels and conditions that determine the effectiveness of SCB. We try to confirm these priors formally through tests of causality between SCB to less procyclicality, given the performance of different budget institution dimensions. Equation (6) is estimated for several groups of countries pre-determined to be either strong or weak performers along eights dimensions of the quality of budget institutions mentioned above. The results are reported in Table 4. More precisely, we adopt the following 
two steps. First, for each dimension in turn, we split the initial sample in two subsamples delineated by the median score: high-score countries, which have scores above the median and low-score countries, which have scores below the median. Second, we estimate the model in equation (6) for each of the resulting groups of countries ( 6 for budget stages and 10 for budget characteristics; i.e., two subgroups for each dimension are considered). The key results are as follows. ${ }^{11}$

\section{Budget institutions and the availability of better information}

For countries with a weak score in planning and negotiation, transparency, comprehensiveness, and centrality of the budget, SCB works to reduce fiscal procyclicality by a larger margin than in the baseline ( 50 percent higher).

- $\quad$ Planning and negotiation stage. SCB leads to a significant reduction in procyclicality for countries with a weak planning and negotiation score, while for higher-score countries the effect is not significant [Table 4, rows (1) and (2)]. Quantitatively, the impact of SCB for weak planning and negotiation countries is 50 percent larger than the baseline mitigation effect, as the cyclicality coefficient, $\beta$ decreases by 4.5 percent. Consistent with our supposition above, a weak score for planning and negotiation corresponds to greater room for improvement through SCB (Figure 2).

- $\quad$ Fiscal transparency. For countries with a low level of transparency, improvements in SCB is associated with a sizable reduction [of about 4.8 percent, Table 4, rows (7) and (6)] in procyclicality; whereas it appears to have no effect on countries with a high transparency score. This suggests that countries with opaque budget processes where information availability can largely be improved, tend to benefit the most in terms of a reduction in procyclical fiscal policies; compared with countries with a high score in transparency for which the effects of SCB appears insignificant.

- Comprehensiveness of the budget. For those countries with less comprehensive budgets, that is, that use only limited information on government revenue and expenditure (Appendix IV), SCB is more likely to be effective in reducing procyclicality than for countries with a high score for the comprehensiveness of budget. Indeed, in the former case, receiving an additional TA mission reduces the procyclicality bias by 4.7 percent, while for the latter the bias is reduced by 2 percent [Table 4, rows (11) and (12)]. A comprehensive budget ensures that all elements of government revenue and expenditure are carefully considered, elaborated in detail, and included within a consistent framework for managing public finances. This

\footnotetext{
${ }^{11}$ Ideally the impact of budget institutions on the fiscal cycle should be estimated by expanding equation (6) to include the interaction between $Y$ and the budget institution index $(B I)$ and $B I$ itself, as an additional control. However, the lack of time variation in the budget index precludes us from following this approach.
} 
requires an understanding of the current conjuncture and possible evolution of the budget, which must be informed by good data.

- Centralization of the decision making process. In the top-down approach to budgeting, the finance ministry supported by the cabinet, plays a prominent role in resource allocation decisions. In countries judged to have weaknesses in this regard (with a low score for Top-Down dimension), enhanced SCB could lead to a reduction in the procyclicality of fiscal policies by nearly 5 percent [Table 4, rows (13) and (14)] but has no statistically-significant effect for strong performers. This suggests that more information can help offset deficiencies in budget processes that are highly decentralized.

- Sustainability and credibility. For countries with a weak score in fiscal sustainability and credibility, where the budget is not implemented as approved, the effect of SCB on procyclicality has a higher magnitude, compared with strong performers in that dimension and amounts to about a 5 percent reduction [Table 4 , rows (15) and (16)], compared with 2.7 percent for the latter. The more pronounced effect for weak performers could be explained by the fact that the degree of credibility is to a large extent determined by the realism of the underlying economic and fiscal projections that hinges on data quality. Therefore, improved data quality through SCB should have a greater impact on weak performers.

\section{Budget institutions and the use of the information}

Statistical capacity building could also support better fiscal outcomes through strong budget institutions that are able to effectively leverage more information. Our analysis reveals that SCB has a more pronounced effect in countries with a strong performance in the budget approval and implementation stages, and that make effective use of rules and controls.

- $\quad$ Approval stage. Concerning the approval stage of the budget process, Table 4 rows (3) and (4) shows that SCB has an effect on strong performers (5 percent reduction) in the approval stage of the budget, with no statistically significant effects for low performers. This is also consistent with our view (elaborated above) that countries with higher scores for the approval stage are likely to make better use of increased information and hence, make higher quality forecasts due to a buildup of statistical capacity over time.

- Implementation stage. SCB appears to be the most effective when the implementation dimension of the budget is already strong [Table 4, rows (5) and (6)], with a 14.2 percentage reduction per TA mission, compared with only 0.9 percent reduction in countries with weak performance. This important reduction for high performers could be explained by the difference in their profligate spending behavior. Compared with weak performers, countries with strong implementation scores 
display less procyclical public spending than the baseline. Indeed, countries with strong implementation scores have a procyclical coefficient of about 0.5 , which represents half the baseline level.

- $\quad$ Rules and controls. Strong fiscal rules and controls also amplify the effect of SCB. In Table 4 rows (9) and (10), the influence of SCB on the procyclicality of public spending is statistically significant irrespective of performance, with a higher magnitude in countries with weak rules and controls ( 6 percent against 3 percent procyclicality reduction). This finding suggests a larger benefit from enhanced data quality - associated with SCB — when rules and controls are present.

Overall, two patterns emerge as to when $\mathrm{SCB}$ is the most effective in reducing the pro cyclicality of fiscal policy in developing countries. First, the impact of capacity building is stronger when countries have a dimension of budget institutions that can be improved upon with increased information. This is true for countries with initially weak levels of planning, transparency, sustainability and credibility of the budget, centralization, and comprehensiveness. Second, the effect of capacity building is also more pronounced for countries with a high score in budget institutions associated with a better use of information. This includes countries with high initial levels at the approval stage and implementation stage, and in the presence of effective rules and controls (Figure 3). Consistent with the effect of increased information, SCB appears to have limited gains for countries with a strong planning score or highly transparent budget processes. This result further reinforces the notion that the transmission channel from SCB to less procyclical fiscal policy is via increased transparency and information.

In many countries, forecasting performance could be intentionally poor, even in the presence of sound data and capacity, owing to strategic motives (see Beetsma and others, 2009 and Lledo and Poplawski-Ribeiro, 2013). As an illustration, strategic forecasting happens when at the budget planning stage, growth and revenue projections are overestimated on purpose to reflect existing fiscal targets and rules. The literature on strategic forecasting suggests that strong budget institutions at the planning stage help mitigate this behavior and promote sound policy implementation. Statistical capacity building, which improves transparency through better data quality, timeliness, and frequency, increases the cost of strategic forecasting. This is consistent with our findings on the role of budget institutions. On the one hand, SCB compensates for poor budget planning, transparency, and credibility, which it helps improve. SCB is therefore more effective when the latter aspects are weak. On the other hand, SCB appears more effective in the presence of strong enforceable rules and controls that prevent strategic forecasting. 
Table 4. Statistical Capacity Building and the Budget Process

\begin{tabular}{|c|c|c|c|c|c|c|c|c|c|c|}
\hline \multicolumn{11}{|c|}{ Panel A: Impact of SCB and stages of the budget process (Within fixedeffect estimates) } \\
\hline \multirow{2}{*}{$\begin{array}{l}\text { Stage } \\
\text { Planning and negotiation }\end{array}$} & \multicolumn{2}{|l|}{ Performance } & \multicolumn{2}{|c|}{ GDP growth } & \multicolumn{2}{|c|}{ GDP growth * SCB Index } & \multirow{2}{*}{$\begin{array}{c}\begin{array}{c}\text { Reduction } \\
\text { (Percent) }\end{array} \\
\mathbf{5 . 0}\end{array}$} & \multirow{2}{*}{$\begin{array}{c}\begin{array}{c}\text { Number of } \\
\text { observations }\end{array} \\
407\end{array}$} & \multirow{2}{*}{$\frac{\text { R-squared }}{0.36}$} & \multirow{2}{*}{$\begin{array}{c}\begin{array}{c}\text { Number of } \\
\text { Countries }\end{array} \\
23\end{array}$} \\
\hline & Weak & $(1)$ & $1.02^{\star \star \star}$ & $(0.178)$ & $-0.05^{\star \star}$ & $(0.017)$ & & & & \\
\hline & Strong & $(2)$ & $0.81^{\star \star \star}$ & $(0.198)$ & -0.01 & $(0.021)$ & 1.2 & 313 & 0.15 & 18 \\
\hline \multirow[t]{2}{*}{ Approval } & Weak & $(3)$ & $0.81^{\star \star \star}$ & $(0.114)$ & -0.02 & $(0.018)$ & 2.5 & 447 & 0.37 & 25 \\
\hline & Strong & $(4)$ & $1.07^{\star \star \star}$ & $(0.193)$ & $-0.05^{\star \star \star \star}$ & $(0.014)$ & 4.7 & 273 & 0.26 & 16 \\
\hline \multirow[t]{2}{*}{ Implementation } & Weak & (5) & $1.00^{\star \star \star}$ & $(0.206)$ & -0.01 & $(0.015)$ & 1.0 & 405 & 0.38 & 24 \\
\hline & Strong & $(6)$ & $0.44^{\star \star \star}$ & $(0.126)$ & $-0.06^{\star x \star x}$ & $(0.010)$ & 13.6 & 315 & 0.16 & 17 \\
\hline \multicolumn{11}{|c|}{ Panel B: Impact of SCB and characteristics of the budget process (Within fixedeffect e stimates) } \\
\hline Characteristic & \multicolumn{2}{|l|}{ Performance } & \multicolumn{2}{|c|}{ GDP growth } & \multicolumn{2}{|c|}{ GDP growth * SCB Index } & $\begin{array}{r}\text { Reduction } \\
\text { (Percent) }\end{array}$ & $\begin{array}{c}\text { Number of } \\
\text { observations }\end{array}$ & R-squared & $\begin{array}{l}\text { Number of } \\
\text { Countries }\end{array}$ \\
\hline \multirow[t]{2}{*}{ Transparency } & Weak & (7) & $0.79^{\star \star \star}$ & $(0.142)$ & $-0.04^{\star \star}$ & (0.018) & 5.1 & 435 & 0.32 & 25 \\
\hline & Strong & (8) & $1.05^{\star \star \star}$ & $(0.279)$ & -0.04 & $(0.027)$ & 3.8 & 285 & 0.32 & 16 \\
\hline \multirow[t]{2}{*}{ Rules and controls } & Weak & $(9)$ & $0.98^{\star \star \star}$ & $(0.172)$ & $-0.03^{*}$ & $(0.016)$ & 3.1 & 474 & 0.37 & 28 \\
\hline & Strong & $(10)$ & $0.88^{\star \star \star}$ & $(0.201)$ & $-0.05^{\star \star \star \star}$ & $(0.013)$ & 5.7 & 246 & 0.20 & 13 \\
\hline \multirow[t]{2}{*}{ Comprehensiveness } & Weak & (11) & $0.96^{\star \star \star}$ & $(0.198)$ & $-0.05^{\star \star *}$ & $(0.017)$ & 5.2 & 361 & 0.38 & 20 \\
\hline & Strong & $(12)$ & $1.30^{\star \star \star}$ & $(0.372)$ & -0.02 & $(0.017)$ & 1.5 & 359 & 0.21 & 21 \\
\hline \multirow[t]{2}{*}{ Centralization } & Weak & $(13)$ & $0.96^{\star \star \star}$ & $(0.215)$ & $-0.05^{\star \star}$ & $(0.017)$ & 5.2 & 404 & 0.31 & 23 \\
\hline & Strong & (14) & $0.79^{\star \star \star}$ & $(0.220)$ & -0.03 & $(0.018)$ & 3.8 & 316 & 0.31 & 18 \\
\hline \multirow[t]{2}{*}{ Sustainability and credibility } & Weak & (15) & $0.76^{\star \star \star}$ & $(0.174)$ & -0.04 & $(0.023)$ & 5.3 & 358 & 0.39 & 21 \\
\hline & Strong & (16) & $1.19^{\star \star \star}$ & $(0.279)$ & $-0.03^{\text {** }}$ & $(0.015)$ & 2.5 & 362 & 0.17 & 20 \\
\hline
\end{tabular}

Note: SCB refers to statistical capacity building. Performance is considered weak (strong) if the score is below (above) the median. The baseline fixed-effects panel regression is estimated with all the controls. The table only reports GDP growth and SCB ${ }^{\star} \mathrm{GDP}$ growth coefficients used to compute reduction in procyclicality. Robust standard errors in parentheses. ${ }^{\star \star \star} p<0.01,{ }^{* \star} p<0.05,{ }^{*} p<0.1$ 


\section{Robustness Tests}

In this section, we assess the sensitivity of our findings. We successively use alternative constructions of the SCB index and re-estimate the baseline equation (6) on different subsamples.

With regard to alternative specifications of the SCB index, we consider two additional proxies: (1) the duration of TA missions (i.e., number of mission days) to account for TA's characteristics and to try to capture the effect of knowledge transfer; and (2) the World Bank's statistical capacity index, which includes timeliness and frequency dimensions. We understand that using the number of TA missions could raise concerns about the ability of such data to account for relative cross-country performance. To address this issue, we use the min-max and the standardized versions of our constructed SCB index. The min-max index is the transformation of the aggregate number of TA missions delivered using the minimum and maximum values in the sample: MinMax $S C B_{i t}=\left[S C B_{i t}-\min _{j}\left(S C B_{j t}\right)\right] /\left[\max _{j}\left(S C B_{j t}\right)-\min _{j}\left(S C B_{j t}\right)\right]$, where $\min _{j}\left(S C B_{j t}\right)$ and $\max _{j}\left(S C B_{j t}\right)$ stand for the minimum and the maximum number of TA missions received by a country $i$ in year $t$, respectively. The resulting index is bounded, ranging from 0 to 1 and captures the relative intensity of TA, in the sense that it indicates in a given year, how much SCB a country has received relative to the country that has receive the largest amount. The standardized version of the index measures the intensity of SCB relative to the average country in each period: Standardized $S C B_{i t}=\left(S C B_{i t}-m_{t}\right) / \sigma_{t}$, where $m_{t}$ is the average number of TAs received by countries and $\sigma_{t}$ the standard deviation of the number of TA received, in period $t$.

Using these additional measures, our previous results - dampening effect of SCB on procyclicality - remain unchanged (Table 5, Panel A). The influence of the two variations of the SCB index - min-max and standardized index - on fiscal policies is reflected in Table 5 rows (1)-(3). In each case, the coefficient on the interactions between SCB and GDP growth is negative and significant. The lagged capacity is also associated with fiscal profligacy bias reduction using both the World Bank's statistical capacity index and the cumulative version of our statistical capacity building index that are measure statistical capacity.

With regard to different country samples, we apply our analysis to low-income countries (LIC) and non-LICs, program and non-program countries, and Sub-Saharan African countries (SSA) and non-SSA countries. This allows us to assess the effectiveness of TA in various contexts. Table 5, Panel B reports the results for the various sub-samples considered. SCB leads to a 3.9 percent reduction in LIC's profligacy and no reduction for non-LIC countries. Similar results are obtained for SSA countries for which an additional TA mission leads to a 4 percent reduction in fiscal profligacy and has no statistically significant effect on non-SSA countries. The results obtained for both LICs and SSA reflect their relatively higher room for improvement in the area of statistics. 
Table 5. Robustness Analysis: Statistical Capacity Building and the Cyclicality of Fiscal Policy

\begin{tabular}{|c|c|c|c|c|c|c|c|c|c|c|}
\hline \multicolumn{11}{|c|}{ Panel A: Robustness to various specifications of the SCB index (Within fixed-effect estimates) } \\
\hline Sample & \multicolumn{2}{|l|}{ Index } & \multicolumn{2}{|c|}{ GDP growth } & \multicolumn{2}{|c|}{ GDP growth * SCB Index } & & \multirow{3}{*}{$\begin{array}{l}\text { No. of obs. } \\
\begin{array}{c}548 \\
548\end{array}\end{array}$} & \multirow{2}{*}{$\begin{array}{c}R^{2} \\
1.872\end{array}$} & \multirow{2}{*}{$\begin{array}{c}\text { No. of Countries } \\
60\end{array}$} \\
\hline Developing & SCB, duration & -1 & $1.327^{\star \star *}$ & $(0.285)$ & $-0.059^{* * *}$ & $(0.020)$ & & & & \\
\hline countries & SCB, min-max & (2) & $1.315^{* * *}$ & $(0.284)$ & $-3.499 * * *$ & $(1.266)$ & & & 1.436 & 60 \\
\hline & SCB, standardizec & (3) & $0.991^{* * *}$ & $(0.290)$ & $-0.464^{\star *}$ & $(0.184)$ & & 548 & 2.876 & 60 \\
\hline \multirow{2}{*}{ Capacity } & WBSCl & (4) & $3.149 * *$ & $(1.218)$ & $-0.026^{*}$ & $(0.014)$ & & 531 & 0.199 & 62 \\
\hline & Cumulative SCB & (5) & $1.246 * * *$ & $(0.291)$ & $-0.136^{*}$ & $(0.069)$ & & 914 & 0.235 & 62 \\
\hline \multicolumn{11}{|c|}{ Pannel B: Robustness to various country samples } \\
\hline Sample & \multirow[t]{2}{*}{ Index } & & \multicolumn{2}{|c|}{ GDP growth } & \multicolumn{2}{|c|}{ GDP growth * SCB Index } & Reduction in percent & No. of obs. & $\mathrm{R}^{2}$ & No. of Countries \\
\hline LIC & & (6) & $1.038^{* * *}$ & $(0.251)$ & $-0.041^{* *}$ & $(0.027)$ & 3.9 & 511 & 0.240 & 29 \\
\hline Non-LICs & \multirow{5}{*}{ SCB } & (7) & $0.974^{* * *}$ & $(0.239)$ & -0.011 & $(0.012)$ & 1.1 & 585 & 0.154 & 33 \\
\hline SSA & & (8) & $1.062^{\star \star *}$ & $(0.166)$ & $-0.043^{* *}$ & $(0.017)$ & 4.0 & 686 & 0.205 & 39 \\
\hline Non-SSA & & (9) & $0.688^{* *}$ & $(0.245)$ & -0.027 & $(0.027)$ & 3.9 & 410 & 0.231 & 23 \\
\hline Program & & (10) & $1.272^{\star \star *}$ & $(0.392)$ & -0.081 & $(0.056)$ & 6.4 & 176 & 0.423 & 55 \\
\hline Non-program & & (11) & $1.020^{\star * *}$ & $(0.164)$ & $-0.028^{* *}$ & $(0.014)$ & 2.7 & 920 & 0.162 & 62 \\
\hline
\end{tabular}

Note: SCB refers to statistical capacity building, LIC to low-income countries, and SSA to Sub-Saharan African countries; WBSCl refers to the World Bank's

Statistical Capacity Building Index. Robust standard errors in parentheses. ${ }^{* *} p<0.01,{ }^{* *} p<0.05,{ }^{*} p<0.1$ 


\section{CONCLUSION}

In this paper, we derive a "statistical capacity building index," which brings together a number of macroeconomic statistics dimensions that are likely to improve budget forecasting performance. These dimensions are measured by the number of statistics-related TA missions provided by the IMF. Applying this index to panel data for 62 developing countries over the period 1990-2012, we find that statistical capacity building leads to a (statistically significant) reduction in fiscal procyclicality. This result is maintained after controlling for institutions and financing constraints, which are the two most important determinants of fiscal procyclicality found in the empirical literature.

The main transmission channels seem to be related to existing budget institutions and countries' performance in different stages of the budget process. We find the impact of statistical capacity building is stronger when countries are relatively weak in certain aspects of budget institutions that could be improved with increased information (e.g., poor planning, lack of transparency), or have strong performance in budget institutions that could presumably make better use of information (e.g., strong implementation, transparent rules and controls).

Our results suggest an alternative way to assess the return on SCB - in terms of improvements in policy making - and indicate that efforts to build statistical capacity could help to improve fiscal policy performance in developing countries. In particular, our findings provide support for further assisting these countries to enhance the level of information, for instance, through more and better quality data and by making better use of the information available. 
APPENDIX I. COUNTRY LIST

\begin{tabular}{llll}
\hline \multicolumn{3}{c}{ Sample of developing countries conside red } \\
\hline Algeria & Côte d'Ivoire & Lesotho & Paraguay \\
Angola & Djibouti & Liberia & Philippines \\
Armenia & El Salvador & Madagascar & Rwanda \\
Bangladesh & Eritrea & Malawi & Senegal \\
Benin & Ethiopia & Mali & Sierra Leone \\
Bolivia & Gabon & Mauritania & Sri Lanka \\
Botswana & Gambia & Moldova & Sudan \\
Burkina Faso & Ghana & Mongolia & Swaziland \\
Burundi & Guatemala & Morocco & Tajikistan \\
Cambodia & Guinea & Mozambique & Tanzania \\
Cameroon & Guinea-Bissau & Namibia & Togo \\
Cape Verde & Haiti & Nepal & Uganda \\
Central African Rep. & Honduras & Nicaragua & Uzbekistan \\
Chad & Indonesia & Niger & Zambia \\
Comoros & Kenya & Nigeria & \\
Congo, D.R. & Kyrgyz Republic & Pakistan & \\
\hline
\end{tabular}


APPENDIX II. KEY VARIABLES

\begin{tabular}{|c|c|c|}
\hline Variable & Description & Data sources \\
\hline Real GDP growth & Growth rate of the real GDP & World Economic Outlook (WEO) \\
\hline Government expenditure & General government total expenditure & World Economic Outlook (WEO) \\
\hline Polity 2 & $\begin{array}{l}\text { Degree of democracy. The polity } 2 \text { score ranges } \\
\text { from }-10 \text { to }+10 \text {, with higher value representing more } \\
\text { democracy. }\end{array}$ & Polity IV project \\
\hline Aid & Net official development aid assistance & World Development Indicators (WDI) \\
\hline
\end{tabular}

TA (technical assistance) missions used to compute the statistical capacity index (SCB index)

WBSC

Program

Budget institutions

Planning and negotiation stage

Approval stage

Implementation stage

Fiscal transparency

Rules and controls

Comprehensiveness of the budget

Centralization of the budget

Sustainability and credibility
Data on the IMF's statistical TA missions. The TA considered are on national accounts (NAS), prices (PR), monetary and financial statistics (MFS), and government finance statistics (GFS). The SCB index is the equally-weighted average of these four dimensions.

World Bank Statistical Capacity Index, which aggregates scores for three categories (Methodology, Source Data, and Periodicity).

The IMF's TA Information Management System (TAIMS), which records TA missions by beneficiary country or region, date, duration, and other characteristics.

World Bank's statistical capacity database (http://datatopics.worldbank.org/statisti calcapacity/)

Dummy variable that takes a value of 1 if the country IMF has an IMF program and 0 otherwise.

The dataset records the quality of budget institutions Dabla-Norris and others (2010). along two dimensions: (i) the various stages in the budget process (planning, approval, and implementation); and (ii) various characteristics of the budget process (the degree of centralization of budgetary decision-making, the existence and effectiveness of rules and controls, the sustainability and credibility of the budget, and the comprehensiveness and transparency). 
ApPendix III. Granger Causality Tests Between Expenditure GroWTH AND GDP GROWTH

\begin{tabular}{lcc}
\hline Dependent variable & Expenditure growth & GDP growth \\
\hline & & \\
GDP Growth, lagged & $\mathbf{- 0 . 1 2 0 ^ { * * }}$ & $0.185^{\star * *}$ \\
& $\mathbf{( 0 . 0 5 3 3 )}$ & $(0.0554)$ \\
Expenditure growth, lagged & $0.662^{* * *}$ & $\mathbf{0 . 0 0 5 7 4}$ \\
& $(0.196)$ & $\mathbf{( 0 . 0 1 5 7 )}$ \\
Constant & $3.999^{* * *}$ & $3.553^{* * *}$ \\
& $(0.878)$ & $(0.198)$ \\
& & \\
\hline Observations & 1,034 & 1,034 \\
R-squared & 0.048 & 0.042 \\
Number of countries & 62 & 62 \\
Dependent lags & 1 & 1 \\
Independent lags & 1 & 1 \\
F-test & $\mathrm{F}(1,61)=11.41$ & $\mathrm{~F}(1,61)=0.13$ \\
& Prob $>\mathrm{F}=0.0013$ & $\mathrm{Prob}>\mathrm{F}=0.7153$ \\
Causal inference & Causality & no causality \\
\hline Robust standard errors are in parentheses. ${ }^{* *} \mathrm{p}<0.01,{ }^{* *} \mathrm{p}<0.05,{ }^{*} \mathrm{p}<0.1$.
\end{tabular}




\section{APPENDIX IV. DIFFERENT DIMENSIONS OF BUDGET INSTITUTIONS}

\section{Stages and categories of the budget process}

Dabla-Norris and others, 2010 identify three consecutive phases in the budget process: planning and negotiation; approval; and implementation. The planning and negotiation phase comprises the establishment of the overall budget and the allocation of funds between the different line ministries and programs. The approval phase comprises the legislature's hearing and legal adoption of the annual budget. The implementation phase includes the execution, monitoring, control, reporting, and external oversight of budgetary allocations. At each of the budgetary stages, five cross-cutting categories are identified: (1) top-down procedures; (2) rules and controls; (3) sustainability and credibility; (4) comprehensiveness; and (5) transparency.

- The top-down budgeting procedure is defined as the extent to which the central budget authority (CBA) under the supervision of the cabinet or council of ministers, is given the agenda-setting role in relation to the main budgetary aggregates, ensuring compliance with the budget laws, and enforcing control of budgetary expenditures.

- The rules and controls dimension measures the presence of budgetary rules that put specific limits on spending and borrowing, including both numerical and procedural rules and controls. While numerical rules are restrictions on the outturn of relevant fiscal variables which establish clear and stable objectives for fiscal policy. Procedural rules define the processes under which budget decisions are made and executed.

- The sustainability and credibility dimension measures the extent to which the budget is implemented as it was approved, which depends on the realism of the underlying economic and fiscal projections, the extent to which the budgetary cost of policy decisions are taken into account, and the effectiveness of arrangements for overseeing and monitoring the budget process.

- The comprehensiveness dimension measures the extent to which all elements of government revenue and expenditure are included within a consistent framework for managing public finances and ensures greater awareness of the current state and future evolution of public finances.

- The transparency dimension measures the extent to which the budget process provides the public with all relevant information in a reliable, timely, understandable, and internationally comparable manner and ensures that public officials are held accountable for managing public resources.

Each dimension of budget institutions is made up of several individual criteria aggregated by simple average. The criteria are measured by scores from surveys, with a higher score reflecting better performance. 


\section{REFERENCES}

Alesina, Alberto, and Roberto Perotti, 1996, "Income distribution, political instability, and investment," European Economic Review, Vol. 40, No. 6, pp. 1203-1228.

Alesina, Alberto, Filipe R. Campante, and Guido Tabellini, 2008, "Why is fiscal policy often procyclical?" Journal of the European Economic Association, Vol. 6, No. 5, pp. 1006-1036.

Alexander, William Edward, John Cady, and Jesus Gonzalez-Garcia, eds. The IMF's Data Dissemination Initiative after 10 Years. International Monetary Fund, 2008.

Alt, James and David Lassen, 2006, "Fiscal Transparency, Political Parties, and Debt in OECD Countries,” European Economic Review, Vol. 50, No. 6, pp. 1401-1439.

Arreaza, Adriana, Bent E. Sorensen, and Oved Yosha, 1998, "Consumption smoothing through fiscal policy in OECD and EU countries," NBER Working Papers No. w6372. National Bureau of Economic Research.

Avellan, Leopoldo, and Guillermo Vuletin, 2015, "Fiscal procyclicality and output forecast errors," Journal of International Money and Finance, Vol. 55, pp. 193-204.

Balassone, Fabrizio, and Manmohan Kumar, 2007, "Cyclicality of fiscal policy,” in Promoting Fiscal Discipline, ed. by Manmohan S. Kumar and Teresa Ter-Minassian (Washington: International Monetary Fund), pp. 19-35.

Beetsma, Roel, and Massimo Giuliodori, 2010, "Fiscal adjustment to cyclical developments in the OECD: an empirical analysis based on real-time data," Oxford Economic Papers, Vol. 62, No. 3, pp. 419-441.

Beetsma, Roel, Massimo Giuliodori, and Franc Klaassen, 2009, "Temporal aggregation and SVAR identification, with an application to fiscal policy," Economics Letters, Vol. 105, No. 3, pp. 253-255.

Calderón, C., Duncan, R., and Schmidt-Hebbel, K., 2004, "Institutions and cyclical properties of macroeconomic policies," Central Bank of Chile working Papers, No. 285, Santiago, Chile.

Cebotari, A., Davis, J. M., Lusinyan, L., Mati, A., Mauro, P., Petrie, M., and Velloso, R., 2009, "Fiscal risks: Sources, disclosure, and management," Washington: Fiscal Affairs Department, International Monetary Fund.

Dabla-Norris, E., Allen, R., Zanna, L. F., Prakash, T., Kvintradze, E., Lledo, V., and Gollwitzer, S., 2010, "Budget institutions and fiscal performance in low-income 
countries," IMF Working Paper WP/10/80 (Washington: International Monetary Fund).

Diallo, Oumar, 2009, “Tortuous road toward countercyclical fiscal policy: Lessons from democratized sub-Saharan Africa," Journal of Policy Modeling, Vol. 31, No. 1, pp. 36-50.

Frankel, Jeffrey A., Carlos A. Végh, and Guillermo Vuletin, 2013, “On graduation from fiscal procyclicality," Journal of Development Economics, Vol. 100, No. 1, pp. 32-47.

Gavin, Michael, and Roberto Perotti, 1997, "Fiscal policy in Latin America," NBER Macroeconomics Annual, Vol. 12, pp. 11-72, MIT Press.

Guillaumont, Jeanneney, S., and S. Tapsoba, 2012, "Aid and income stabilization," Review of Development Economics, Vol. 16, No. 2, pp. 216-229.

Ilzetzki, Ethan, 2011, "Rent-seeking distortions and fiscal procyclicality," Journal of Development Economic, Vol. 96, No. 1, pp. 30-46.

Ilzetzki, Ethan, and Carlos A. Végh, 2008, "Procyclical fiscal policy in developing countries: Truth or fiction?" NBER Working Papers No. w14191, National Bureau of Economic Research.

Jonung, Lars, and Martin Larch, 2006, "Improving fiscal policy in the EU: the case for independent forecasts," Economic Policy, Vol. 21, No. 47, pp. 491-534.

Kaminsky, Graciela L., Carmen M. Reinhart, and Carlos A. Végh., 2005, "When it rains, it pours: procyclical capital flows and macroeconomic policies," NBER Macroeconomics Annual, Vol. 19, pp. 11-82, MIT Press.

Lane, Philip R., 2003, "The cyclical behavior of fiscal policy: evidence from the OECD," Journal of Public Economics, Vol. 87, No. 12, pp. 2661-2675.

Leal, Teresa, Javier J. Pérez, Mika Tujula, and Jean-Pierre Vidal, 2008, "Fiscal Forecasting: Lessons from the Literature and Challenges," Fiscal Studies, Vol. 29, No. 3, pp. 347-386.

Ley, Eduardo, and Florian Misch, 2014, "Output Data Revisions in Low-Income Countries," New Perspectives.

Lledo, V., and Poplawski-Ribeiro, M., 2013, "Fiscal Policy Implementation in Sub-Saharan Africa," World Development, Vol. 46, pp. 79-91.

Lledó, Victor D., Irene Yackovlev, and Lucie Gadenne, 2011, "A tale of cyclicality, aid flows and debt: Government spending in sub-Saharan Africa," Journal of African Economies, Vol. 20, No. 5, pp. 823-849. 
Manasse, Paolo, 2006, "Procyclical Fiscal Policy: Shocks, Rules, and Institutions-A View from MARS,” IMF Working Paper WP/06/27 (Washington: International Monetary Fund).

Mpatswe, Gaston, K., Sampawende J.-A. Tapsoba, and Robert C. York, 2011, "The Cyclicality of Fiscal Policies in the CEMAC Region," IMF Working Paper WP/11/205 (Washington: International Monetary Fund).

Mrkaic, Mico, 2010, “Data Dissemination Standards and the Statistical Quality of the IMF's World Economic Outlook Forecasts," IMF Working Paper WP 10/203 (Washington:

International Monetary Fund).

Pallage, Stéphane, and Michel A. Robe, 2001, "Foreign aid and the business cycle," Review of International Economics, Vol. 9, No. 4, pp. 641-672.

Riascos, Alvaro, and Carlos A. Vegh, 2003, "Procyclical government spending in developing countries: The role of capital market imperfections," International Monetary Fund.

Strawczynski, M., and Zeira, J., 2011, "Procyclicality of fiscal policy in Emerging Countries: The cycle is the trend," Documentos de Trabajo (Banco Central de Chile), No. 624.

Talvi, Ernesto, and Carlos A. Vegh, 2005, "Tax base variability and procyclical fiscal policy in developing countries," Journal of Development Economics, Vol. 78, No. 1, pp. 156-190.

Thornton, John, 2008, "Explaining Procyclical Fiscal Policy in African Countries," Journal of African Economies, Vol. 17, No. 3, pp. 451-464.

Tornell, Aaron, and Philip R. Lane, 1998, “Are windfalls a curse? A non-representative agent model of the current account," Journal of International Economics, Vol. 44, No. 1, pp. 83112.

Tornell, Aaron, and Philip R. Lane, 1999, "The voracity effect," American Economic Review, Vol. 89, No. 1, pp. 22-46.

Velasco, Andres, 1997, "A model of endogenous fiscal deficits and delayed fiscal reforms," NBER Working Papers No. w6336, National Bureau of Economic Research.

Wieland, V., and Wolters, M. H., 2011, "Forecasting and policy making," Preparation for G. Elliott and A. Timmermann (eds.), Handbook of Economic Forecasting, Vol. 2. 